\title{
Morphometric comparison of the growth curve in Nile tilapia (Oreochromis niloticus) sexually reverted to masculinized and feminized
}

\author{
Ricardo Chávez-García ${ }^{1}$, Alejandra Contreras-Ramos ${ }^{2}$, Clara Ortega-Camarillo ${ }^{3}$ \\ Gerardo Figueroa-Lucero ${ }^{4}$, Guadalupe Prado-Flores ${ }^{5}$ \\ Germán Mendoza-Martínez ${ }^{5}$ \& Marcela Vergara-Onofre ${ }^{5}$ \\ ${ }^{1}$ Doctorado en Ciencias Agropecuarias, Universidad Autónoma Metropolitana, Unidad Xochimilco \\ Ciudad de México, México \\ ${ }^{2}$ Laboratorio de Biología del Desarrollo y TE, HIMFG, Ciudad de México, México \\ ${ }^{3}$ Unidad de Investigación Médica en Bioquímica, Hospital de Especialidades, Centro Médico Nacional \\ Siglo XXI, Instituto Mexicano del Seguro Social, Ciudad de México, México \\ ${ }^{4}$ Planta Experimental de Producción Acuícola, Universidad Autónoma Metropolitana \\ Iztapalapa, Ciudad de México, México \\ ${ }^{5}$ Departamento de Producción Agrícola y Animal, Universidad Autónoma Metropolitana \\ Xochimilco, Ciudad de México, México \\ Corresponding author: Marcela Vergara-Onofre (mvergara@correo.xoc.uam.mx)
}

\begin{abstract}
Aquaculture is an industry in development around the world that allows covering the nutritional demand with a high nutritional value. Within this industry, monosex crops of some species, such as the Nile tilapia (Oreochromis niloticus), stand out. In this study, the effect of the administration of $17 \alpha$-ethinyl estradiol and $17 \alpha$-methyltestosterone on the morphometry of Nile tilapia at different times was evaluated. Nile tilapia were raised under controlled conditions and divided into three groups: control: no hormone treatment; feminized: treated with $17 \alpha$-ethynyl estradiol and masculinized: treated with $17 \alpha$-methyltestosterone. The measurements were made at 5, 10, 15, 25, 35, 40, 50, 60 and 70 days after fertilization with the morphometric technique "truss protocol." The data were analyzed using a general linear model of repeated measurements and analysis of variance of comparison of means. The growth curve was made using the Gompertz logistic model. The results showed that the masculinized larva presented a higher growth rate and increased daily gain of weight $2.05^{-2} \mathrm{mg}$ compared to the controls and feminized $1.67^{-3} \mathrm{mg}$ and $7.57^{-4} \mathrm{mg}$, respectively. The sexual reversion of Nile tilapia with $17 \alpha$-methyltestosterone increases the growth curve of the masculinized organism and the uniformity of the final size.
\end{abstract}

Keywords: Oreochromis niloticus; morphometry; sexual reversal; $17 \alpha$-ethynyl estradiol; $17 \alpha$-methyltestosterone

\section{INTRODUCTION}

Aquaculture participates in the human diet with 59.4 million $t$ worldwide, where Mexico contributes with $1.1 \%$ of the fishing and aquaculture production (Hasan $\&$ Halwart, 2009). Currently, there has been an increase in interest in the cultivation of masculinized Nile tilapia Oreochromis niloticus (El-Greisy \& El-Gamal, 2012; Megbowon \& Mojekwu, 2013), mainly due to its accelerated growth, good adaptation to different environmental conditions and its high level of nutrition- nal quality (Chakraborty et al., 2011; Hasheesh et al., 2011; Junior et al., 2012). However, the traditional crop of tilapia, constituted mainly by heterosexual organisms, has some drawbacks such as early maturation, a high percentage of fertility and frequent spawning (Minton, 2009) That increases the presence of juveniles and the variation in the size and weight of the fish at the time of harvest (Ezaz et al., 2004). These drawbacks impose a decrease in their economic productivity. Several strategies have been developed to avoid this, producing monosex crops mainly of males (Juárez-Juárez et al.,

Corresponding editor: Mauricio Laterça 
2017). In the cultivation of masculinized organisms, a high and homogeneous rate of body growth is maintained (Junior et al., 2012), avoiding variations in the size of the harvest and uncontrolled reproduction (Megbowon \& Mojekwu, 2013).

There are several strategies to obtain monosex crops, among which are the classification by manual sexing, hybridization of organisms, chromosomal and genetic manipulations, in addition to sexual reversion through the administration of synthetic sex hormones (Chakraborty et al., 2011; Megbowon \& Mojekwu, 2013). Of these procedures, the hormonal sexual reversion is the one that best adapts to the production of large-scale masculinized tilapia. The hormones commonly used are 19 norethyltestosterone, fluoxi testosterone, 17 $\alpha$-methyltestosterone (Ong et al., 2012), mesterelone, androstenedione, trenbolone acetate (Golan \& Levavi-Sivan, 2014) and 17 $\alpha$ methyldihydrotestosterone (Passantino, 2012). The most frequently used hormone in this field is $17 \alpha-$ methyltestosterone (MT) due to its easy handling and high effectiveness (95 to $100 \%$ of the men's organism) (Celik et al., 2011; Hasheesh et al., 2011).

The purpose of this study was to review the effect of the administration of androgenic and estrogenic hormones on the morphometry of Nile tilapia crops.

\section{MATERIALS AND METHODS}

\section{Animals}

Five breeding pairs of Oreochromis niloticus from the Aquaculture Center (CONAPESCA) of Zacatepec Morelos were obtained; they were housed by sex in the Aquaculture Production Experimental Plant of the Autonomous Metropolitan University Campus Iztapalapa, in $250 \mathrm{~L}$ tanks. The organisms were maintained at a temperature between 28 and $30^{\circ} \mathrm{C}, \mathrm{pH}$ of 6.8 to 7 in the water, oxygen concentration of 3.5 to $5 \mathrm{mg} \mathrm{L}^{-1}$, and a photoperiod of 14 light: 10 dark. The fish received commercial feed (Purina ${ }^{\circledR}$ ) two times a day. The food presented 53\% protein and $15 \%$ fat in a particle meal less than $0.35 \mathrm{~mm}$. The pairs were chosen at random, to obtain gametes, and the spawning was performed manually, later the male and female gametes were incubated in a McDonald's chamber with a volume of $10 \mathrm{~L}$ of water for artificial insemination.

\section{Treatments}

Once the artificial fertilization was carried out, approximately 200 eggs were incubated in each treatment of $O$. niloticus in $80 \mathrm{~L}$ tanks where under the immersion technique they underwent the experimental treatments and were assigned to one of three experimental groups: control: without hormonal treatment; feminized: $200 \mu \mathrm{g} \mathrm{L}^{-1}$ of $17 \alpha$-ethinyl estradiol (SigmaAldrich E4876) for 18 days to obtain $100 \%$ of the females (Wassermann \& Afonso, 2003); masculinized: $1,800 \mu \mathrm{g} \mathrm{L}^{-1}$ of $17 \alpha$-methyltestosterone (Sigma-Aldrich M7252) for $4 \mathrm{~h}$ to obtain $100 \%$ of the males (Gilling et al., 1996).

\section{Morphometric measurements}

The morphometric technique proposed by Strauss \& Bookstein (1982) "truss protocol" was used, which consists of a system of measurements of vertical, horizontal and oblique distances between specific preselected anatomical points. These data are identified on selected morphological characters with which the body is divided into functional units. The measurements were done to 15 larvae per treatment at $5,10,15,25$, $35,40,50,60$ and 70 days after fertilization, using a total of 135 larvae in the study. The values obtained were the following, the total length that was measured from the head to the caudal fin, the standard length from the head to the furcation with an ichthyometer, the height of the individuals from the ventral fin to the dorsal fin and the total weight registered with an analytical balance.

\section{Statistical analysis}

The results were analyzed with the general linear model of repeated measures, an analysis of variance of comparison of means was performed. The normality and homogeneity of the variance were determined by the Kolmogorov-Smirnov test and a comparison analysis of Tukey's means $(P<0.05)$ was performed using the JMP version 9 program.

To evaluate the growth curve, the Gompertz logistic model was used, which is expressed by the following equation:

$$
\mathrm{yt}=\mathrm{A} \exp ^{[-\mathrm{B} \exp (-\mathrm{Kt})]}
$$

where yt: the weight of the organism at the end of the measured time, A: weight at maturity, B: integration parameter that does not correspond to a biological character, K: maturity index or the degree of maturity precocity of the individual, and t: time.

\section{RESULTS}

In this study, it was observed that the organisms masculinized with $17 \alpha$-methyl testosterone have higher values of the morphometric measurements studied, concerning the feminized ones with 17a-ethynyl estradiol and controls. The effect of the treatment of each group on the morphometric measurements was compared against the control treatment. The total length of the masculinized fish was higher and statisti- 
Table 1. Effect of the evaluated treatment on the total length in Oreochromis niloticus. n: 15 individuals per time; a: expresses the literal that shows the greatest growth in comparison with the letter $\mathrm{b}$ and $\mathrm{c}$. Different letters between columns show significant differences $(P<0.0001)$.

\begin{tabular}{cccrcc}
\hline $\begin{array}{c}\text { Time } \\
(\text { days })\end{array}$ & $\begin{array}{c}\text { Feminized } \\
(\mathrm{cm})\end{array}$ & $\begin{array}{c}\text { Masculinized } \\
(\mathrm{cm})\end{array}$ & $\begin{array}{c}\text { Control } \\
(\mathrm{cm})\end{array}$ & $\begin{array}{c}\text { Standard } \\
\text { error }\end{array}$ & $P$-value \\
\hline 5 & $0.81 \pm 0.13^{\mathrm{b}}$ & $1.08 \pm 0.13^{\mathrm{a}}$ & $0.81 \pm 0.19^{\mathrm{b}}$ & 0.03 & $<0.0001$ \\
10 & $0.82 \pm 0.12^{\mathrm{c}}$ & $1.17 \pm 0.17^{\mathrm{a}}$ & $1.02 \pm 0.08^{\mathrm{b}}$ & 0.03 & $<0.0001$ \\
15 & $0.72 \pm 0.09^{\mathrm{c}}$ & $1.30 \pm 0.15^{\mathrm{a}}$ & $0.92 \pm 0.16^{\mathrm{b}}$ & 0.04 & $<0.0001$ \\
25 & $0.9 \pm 0.11^{\mathrm{b}}$ & $3.48 \pm 0.44^{\mathrm{a}}$ & $1.24 \pm 0.12^{\mathrm{b}}$ & 0.16 & $<0.0001$ \\
35 & $1.04 \pm 0.12^{\mathrm{b}}$ & $3.85 \pm 0.19^{\mathrm{a}}$ & $1.37 \pm 0.20^{\mathrm{b}}$ & 0.16 & $<0.0001$ \\
40 & $1.10 \pm 0.09^{\mathrm{c}}$ & $4.36 \pm 0.20^{\mathrm{a}}$ & $1.3 \pm 0.21^{\mathrm{b}}$ & 0.44 & $<0.0001$ \\
50 & $1.21 \pm 0.09^{\mathrm{b}}$ & $4.52 \pm 0.19^{\mathrm{a}}$ & $1.60 \pm 0.20^{\mathrm{b}}$ & 0.19 & $<0.0001$ \\
60 & $1.31 \pm 0.09^{\mathrm{b}}$ & $4.90 \pm 0.19^{\mathrm{a}}$ & $1.7 \pm 0.20^{\mathrm{b}}$ & 0.20 & $<0.0001$ \\
70 & $1.41 \pm 0.09^{\mathrm{b}}$ & $5.40 \pm 0.20^{\mathrm{a}}$ & $1.84 \pm 0.20^{\mathrm{b}}$ & 0.20 & $<0.0001$ \\
\hline
\end{tabular}

Table 2. Effect of the evaluated treatment on the total pattern in Oreochromis niloticus. n: 15 individuals per time; a: expresses the literal that shows the greatest growth in comparison with the letter $\mathrm{b}$ and $\mathrm{c}$. Different letters between columns show significant differences $(P<0.0001)$.

\begin{tabular}{cccccc}
\hline $\begin{array}{l}\text { Time } \\
(\text { days })\end{array}$ & $\begin{array}{c}\text { Feminized } \\
(\mathrm{cm})\end{array}$ & $\begin{array}{c}\text { Masculinized } \\
\mathrm{cm})\end{array}$ & $\begin{array}{c}\text { Control } \\
(\mathrm{cm})\end{array}$ & $\begin{array}{c}\text { Standard } \\
\text { Error }\end{array}$ & $P$-value \\
\hline 5 & $0.52 \pm 0.12^{\mathrm{b}}$ & $0.82 \pm 0.12^{\mathrm{a}}$ & $0.56 \pm 0.09^{\mathrm{b}}$ & 0.03 & $<0.0001$ \\
10 & $0.59 \pm 0.12^{\mathrm{b}}$ & $0.92 \pm 0.15^{\mathrm{a}}$ & $0.58 \pm 0.11^{\mathrm{b}}$ & 0.04 & $<0.0001$ \\
15 & $0.514 \pm 0.08^{\mathrm{c}}$ & $1.05 \pm 0.14^{\mathrm{a}}$ & $0.69 \pm 0.17^{\mathrm{b}}$ & 0.04 & $<0.0001$ \\
25 & $0.68 \pm 0.10^{\mathrm{b}}$ & $3.12 \pm 0.37^{\mathrm{a}}$ & $0.94 \pm 0.11^{\mathrm{b}}$ & 0.13 & $<0.0001$ \\
35 & $0.79 \pm 0.14^{\mathrm{b}}$ & $3.60 \pm 0.20^{\mathrm{a}}$ & $1.13 \pm 0.20^{\mathrm{b}}$ & 0.16 & $<0.0001$ \\
40 & $0.87 \pm 0.12^{\mathrm{b}}$ & $3.89 \pm 0.20^{\mathrm{a}}$ & $1.25 \pm 0.20^{\mathrm{b}}$ & 0.17 & $<0.0001$ \\
50 & $0.91 \pm 0.12^{\mathrm{b}}$ & $4.2 \pm 0.20^{\mathrm{a}}$ & $1.3 \pm 0.19^{\mathrm{b}}$ & 0.18 & $<0.0001$ \\
60 & $0.94 \pm 0.12^{\mathrm{b}}$ & $4.48 \pm 0.23^{\mathrm{a}}$ & $1.4 \pm 0.19^{\mathrm{b}}$ & 0.2 & $<0.0001$ \\
70 & $0.97 \pm 0.11^{\mathrm{b}}$ & $4.92 \pm 0.23^{\mathrm{a}}$ & $1.61 \pm 0.19^{\mathrm{b}}$ & 0.22 & $<0.0001$ \\
\hline
\end{tabular}

cally significant $(P<0.001)$ in all the times of measurement in comparison to the feminized organisms and those of the control treatment. On the contrary, the feminized organisms showed a decrease in the total length concerning controls and masculinized (23 and $75 \%$, respectively) (Table 1). The effect of the treatment is evident after 15 days of age.

The total pattern shown in (Table 2) indicates that the masculinized organisms present a significant increase concerning the feminized organisms and the control treatment, giving the most outstanding effect after 25 days of age $(P<0.001)$.

The treatment with $17 \alpha$-methyltestosterone increases the height of the organisms from day 25 in comparison to the control and feminized treatments $(P$ $<0.001$ ) (Table 3). The heights recorded in the masculinized organisms for all measurement times show significant differences $(P<0.001)$.

The response of the hormonal treatments on the growth rate shows significant differences $(P<0.001)$ in the masculinized organisms, which present a more significant growth in proportion to the organisms of the control treatment and the feminized ones; in addition, it is observed that these organisms present a higher daily weight gain (Table 4).

\section{DISCUSSION}

The results indicate that the hormone $17 \alpha$-methyltestosterone induces a positive effect in the increase of the morphometric measurements in comparison to the control and feminized organisms, which is an aquaculture production that could increase the yield of the Nile tilapia Oreochromis niloticus crops, maintaining the uniformity of the sizes of the masculinized organisms. The results of Oponda et al. (2017), who worked with $O$. niloticus, agree with the results we present and support that morphometric behavior ratifies the relationship with the growth rate, depending on the genetic line. The sexual dimorphism that teleost fishes present, indicates a greater response in the growth of the masculine phenotype in masculini- 
Table 3. Effect of evaluated treatment on height in Oreochromis niloticus. n: 15 individuals per time, a: expresses the literal that shows the greatest growth in comparison with the letter b and c. Different letters between columns show significant differences $(P<0.0001)$.

\begin{tabular}{cccccc}
\hline $\begin{array}{l}\text { Time } \\
\text { (days })\end{array}$ & $\begin{array}{c}\text { Feminized } \\
(\mathrm{cm})\end{array}$ & $\begin{array}{c}\text { Masculinized } \\
(\mathrm{cm})\end{array}$ & $\begin{array}{c}\text { Control } \\
(\mathrm{cm})\end{array}$ & $\begin{array}{c}\text { Standard } \\
\text { error }\end{array}$ & $P$-value \\
\hline 5 & $0.12 \pm 0.04^{\mathrm{c}}$ & $0.25 \pm 0.05^{\mathrm{a}}$ & $0.17 \pm 0.04^{\mathrm{b}}$ & 0.04 & $<0.0001$ \\
10 & $0.18 \pm 0.03^{\mathrm{b}}$ & $0.33 \pm 0.05^{\mathrm{a}}$ & $0.20 \pm 0.02^{\mathrm{b}}$ & 0.01 & $<0.0001$ \\
15 & $0.21 \pm 0.02^{\mathrm{c}}$ & $0.29 \pm 0.04^{\mathrm{a}}$ & $0.24 \pm 0.04^{\mathrm{b}}$ & 0.01 & $<0.0001$ \\
25 & $0.23 \pm 0.25^{\mathrm{b}}$ & $0.91 \pm 0.02^{\mathrm{a}}$ & $0.28 \pm 0.04^{\mathrm{b}}$ & 0.04 & $<0.0001$ \\
35 & $0.26 \pm 0.06^{\mathrm{c}}$ & $0.96 \pm 0.07^{\mathrm{a}}$ & $0.44 \pm 0.05^{\mathrm{b}}$ & 0.04 & $<0.0001$ \\
40 & $0.23 \pm 0.06^{\mathrm{c}}$ & $1.11 \pm 0.07^{\mathrm{a}}$ & $0.49 \pm 0.07^{\mathrm{b}}$ & 0.05 & $<0.0001$ \\
50 & $0.31 \pm 0.06^{\mathrm{b}}$ & $1.14 \pm 0.07^{\mathrm{a}}$ & $0.50 \pm 0.07^{\mathrm{c}}$ & 0.07 & $<0.0001$ \\
60 & $0.43 \pm 0.06^{\mathrm{b}}$ & $1.25 \pm 0.07^{\mathrm{a}}$ & $0.50 \pm 0.07^{\mathrm{c}}$ & 0.81 & $<0.0001$ \\
70 & $0.46 \pm 0.06^{\mathrm{b}}$ & $1.413 \pm 0.07^{\mathrm{a}}$ & $0.52 \pm 0.07^{\mathrm{b}}$ & 0.07 & $<0.0001$ \\
\hline
\end{tabular}

Table 4. The treatment effect on Oreochromis niloticus weight. n: 15 individuals per time; a: expresses the literal that shows the greatest growth in comparison with the letter $\mathrm{b}$ and $\mathrm{c}$. Different letters between columns show significant differences $(P$ $<0.0001)$. DGW: daily weight gain.

\begin{tabular}{lccrccc}
\hline Treatment & Growth rate & Standard error & $P$-value & Initial weight $(\mathrm{g})$ & Final weight $(\mathrm{g})$ & DGW $(\mathrm{g})$ \\
\hline Feminized & $0.46^{\mathrm{b}}$ & 0.43 & 0.2832 & $0.01 \pm 0.01^{\mathrm{b}}$ & $0.05 \pm 0.02^{\mathrm{b}}$ & $7.57^{\mathrm{E}-04}$ \\
Masculinized & $3.38^{\mathrm{a}}$ & 0.41 & $<0.0001$ & $0.02 \pm 0.03^{\mathrm{a}}$ & $1.43 \pm 0.18^{\mathrm{a}}$ & $2.05^{\mathrm{E}-02}$ \\
Control & $0.48^{\mathrm{b}}$ & 0.41 & 0.2538 & $0.01 \pm 0.04^{\mathrm{b}}$ & $0.11 \pm 0.06^{\mathrm{b}}$ & $1.67^{\mathrm{E}-03}$ \\
\hline
\end{tabular}

zed organisms with phenotype and genotype $\mathrm{XX}$ in comparison to other species of the same family of teleost fishes, as the case of the flounder fish (Kobelkowsky, 2004), depending very much on the environmental conditions in which the rearing of organisms is found (Santos et al., 2013). The studies conducted by de Oliveira et al. (2016), who evaluated five generations of Nile tilapia, show for each generation an increase in the growth rate of $4 \%$, which markedly improved the daily weight gain, higher yield of the size and fillet obtained from these organisms. Nebo et al. (2013) reported an increase in the diameter of muscle fibers (30 and $40 \mu \mathrm{m})$, which indicated an increase in anabolism and that was reflected in muscle hypertrophy of fish treated with androgenic hormones in the juvenile stage, around 10 to 15 days of age after hormonal treatment. It has been reported that in some aquatic species such as rainbow trout (Oncorhynchus mykiss) and some salmonids (Salmonidae spp.), the muscle represents more than $50 \%$ of the total of the individual and exhibits indeterminate growth, unlike other vertebrates. Among the factors that control the production and maintenance of muscle fibers are the steroid hormones (Koganti et al., 2017). In fish, muscle tissue harbors some hormone receptors that regulate its metabolism, such as alpha and beta estrogen receptors that are activated by the presence of steroid hormones (Nagler et al., 2007; Koganti et al., 2017). In this study, the feminized organisms showed a delay in growth; previous studies claim that the presence of $17 \beta-$ estradiol significantly increases sexual maturation in some aquatic species such as salmonids and rainbow trout. What increases metabolic processes of high energy demand such as follicular development (Lubzens et al., 2010); which leads to an increase in water content in the muscle (Davidson et al., 2014), increased protein degradation, and reduced muscle quality (Cleveland \& Weber, 2011). It has also been observed in fish that $17 \beta$-estradiol decreases the levels of insulin-like growth factor 1 (IGF-1) (Hanson et al., 2014), unlike other species such as rodents, bovines and pigs in which estrogens have anabolic effects (Kamanga-Sollo et al., 2010). The IGF-1-GH (growth hormone) system participates in the regulation of growth, differentiation and maintenance of skeletal muscle homeostasis. IGFs stimulate both myoblast proliferation and differentiation (Duan et al., 2010). So if 17ß-estradiol inhibits IGF-1-GH signaling, then skeletal muscle development and body growth will be affected (Norbeck \& Sheridan, 2011; Lerner et al., 2012).

In some fish, the presence of $17 \beta$-estradiol and some androgens present a negative and positive impact, respectively, in terms of the expression of the genes involved in body growth (Hanson et al., 2014). These effects are mainly related to their signaling towards 
somatotropin and in turn with IGF-1, which is suppressed by the proteolytic mechanisms that cause estrogen in muscle (Lerner et al., 2012). Although sex steroid production increases significantly during sexual maturation, fish may be exposed to natural steroids at juvenile age; the increase of these during the sexual maturation contributes to the decrease of the energetic reserves that, instead of being used for the corporal development, are used for the gonadal development (Cleveland \& Weber, 2015). There is also the possibility that estrogens produce an increase in muscle protein degradation in these fish (Cleveland \& Weber, 2011), since they increase the availability of amino acids during hormonal exposure; while with androgen treatment, anabolic processes are positive and help preserve muscle protein, in addition to positively regulating the expression of IGF-1, IGF-2 and IGF-5 in the muscle of these fish (Bower \& Johnston, 2010).

\section{CONCLUSIONS}

The use of steroids in aquaculture for the sexual reversion of Nile tilapia Oreochromis niloticus favors the growth curve of the masculinized organisms and uniformity of size. However, it is important to know the molecular processes related to muscle development in the presence of steroid hormones.

\section{ACKNOWLEDGMENTS}

To the Biologist Arturo Castañeda in charge of the Aquaculture Center (CONAPESCA) of Zacatepec Morelos, who provided the reproductive organisms and trained in the handling and breeding of the same. To the National Council of Science and Technology (CONACyT) for the scholarship for doctoral studies of Ricardo Chávez García.

\section{REFERENCES}

Bower, N.I. \& Johnston, I.A. 2010. Paralogs of Atlantic salmon myoblast determination factor genes are distinctly regulated in proliferating and differentiating myogenic cells. American Journal of PhysiologyRegulatory, Integrative, and Comparative Physiology, 298(6): R1615-R1626.

Celik, I., Guner, Y. \& Celik, P. 2011. Effect of orallyadministered 17 $\alpha$-Methyltestosterone at different doses on the sex reversal of the Nile tilapia (Oreochromis niloticus Linneaus, 1758). Journal of Animal and Veterinary Advances, 10(7): 853-857.

Chakraborty, S.B., Mazumdar, D., Chatterji, U. \& Banerjee, S. 2011. Growth of mixed-sex and monosex Nile tilapia in different culture systems. Turkish
Journal of Fisheries and Aquatic Sciences, 11(1): 131138.

Cleveland, B.M. \& Weber, G.M. 2011. Effects of sex steroids on indices of protein turnover in rainbow trout (Oncorhynchus mykiss) white muscle. General and Comparative Endocrinology, 174(2): 132-142.

Cleveland, B.M. \& Weber, G.M. 2015. Effects of sex steroids on expression of genes regulating growthrelated mechanisms in rainbow trout (Oncorhynchus mykiss). General and Comparative Endocrinology, 216: 103-115.

Davidson, J.D.P., Brett, P., Manor, M.L., Good, C., Weber, G.M., Aussanasuwannakul, A., Turk, P.J., Welsh, C. \& Summerfelt, S.T. 2014. Growth performance, fillet quality, and reproductive maturity of rainbow trout (Oncorhynchus mykiss) cultured to 5 kilograms within freshwater recirculating systems. Journal of Aquaculture Research \& Development, 5(4): 1-9.

De Oliveira, C.A.L., Ribeiro, R.P., Yoshida, G.M., Kunita, N.M., Rizzato, G.S., De Oliveira, S.N., Dos Santos, A.I. \& Nguyen, N.H. 2016. Correlated changes in body shape after five generations of selection to improve growth rate in a breeding program for Nile tilapia Oreochromis niloticus in Brazil. Journal of Applied Genetics, 57(4): 487-493.

Duan, C., Ren, H. \& Gao, S. 2010. Insulin-like growth factors (IGFs), IGF receptors, and IGF-binding proteins: roles in skeletal muscle growth and differentiation. General and Comparative Endocrinology, 167(3): 344-351.

El-Greisy, Z. \& El-Gamal, A. 2012. Monosex production of tilapia, Oreochromis niloticus using different doses of $17 \alpha$-methyltestosterone with respect to the degree of sex stability after one year of treatment. Egyptian Journal of Aquatic Research, 38(1): 59-66.

Ezaz, M.T., Harvey, S.C., Boonphakdee, C., Teale, A.J., McAndrew, B.J. \& Penman, D.J. 2004. Isolation and physical mapping of sex-linked AFLP markers in Nile tilapia (Oreochromis niloticus L.). Marine Biotechnology, 6(5): 435-445.

Gilling, C., Skibinski, D. \& Beardmore, J. 1996. Sex reversal of tilapia fry by immersion in water containing oestrogens. Third International Symposium on Tilapia in Aquaculture. Manila, Philippines, pp. 314-319.

Golan, M. \& Levavi-Sivan, B. 2014. Artificial masculinization in tilapia involves androgen receptor activation. General and Comparative Endocrinology, 207: 50-55.

Hanson, A.M., Kittilson, J.D., Martin, L.E. \& Sheridan, M.A. 2014. Environmental estrogens inhibit growth of rainbow trout (Oncorhynchus mykiss) by modulating the growth hormone-insulin-like growth factor system. General and Comparative Endocrinology, 196: 130138. 
Hasan, M.R. \& Halwart, M. 2009. Fish and feed inputs for aquaculture. Practices, sustainability and implications. FAO Fisheries and Aquaculture Technical Paper, 518: $424 \mathrm{pp}$.

Hasheesh, W.S., Marie, M.-A.S., Abbas, H.H., Eshak, M.G. \& Zahran, E.A. 2011. An evaluation of the effect of $17 \alpha$-Methyltestosterone hormone on some biochemical, molecular and histological changes in the liver of Nile Tilapia, Oreochromis niloticus. Life Science Journal, 8(3): 343-358.

Juárez-Juárez, V., Alcántar-Vázquez, J.P., AntonioEstrada, C., Marín-Ramírez, J.A. \& Moreno-De La Torre, R. 2017. Feminization by $17 \alpha$-ethinylestradiol of the progeny of XY-female Nile tilapia (Oreochromis niloticus). Effects on growth, condition factor and gonadosomatic index. Turkish Journal of Fisheries and Aquatic Sciences, 17(3): 599-607.

Junior, R. Vargas, L., Valentim-Zabott, M., Ribeiro, R.P., Da Silva, A.V. \& Otutumi, L.K. 2012. Morphometry of white muscle fibers and performance of Nile tilapia (Oreochromis niloticus) fingerlings treated with methyltestosterone or a homeopathic complex. Homeopathy, 101(3): 154-158.

Kamanga-Sollo, E., White, M., Hathaway, M., Weber, W. \& Dayton, W. 2010. Effect of estradiol-17 $\beta$ on protein synthesis and degradation rates in fused bovine satellite cell cultures. Domestic Animal Endocrinology, 39(1): 54-62.

Kobelkowsky, A. 2004. Sexual dimorphism of the flounder Bothus robinsi (Pisces: Bothidae). Journal of Morphology, 260(2): 165-171.

Koganti, P.P. Wang, J., Cleveland, B., Ma, H., Weber, G.M. \& Yao, J. 2017. Estradiol regulates expression of miRNAs associated with myogenesis in rainbow trout. Molecular and Cellular Endocrinology, 443: 1-14.

Lerner, D.T., Sheridan, M.A. \& McCormick, S.D. 2012. Estrogenic compounds decrease growth hormone receptor abundance and alter osmoregulation in Atlantic salmon. General and Comparative Endocrinology, 179(2): 196-204.

Lubzens, E., Young, G., Bobe, J. \& Cerdà, J. 2010. Oogenesis in teleosts: how fish eggs are formed. General and Comparative Endocrinology, 165(3): 367-389.

Megbowon, I. \& Mojekwu, T. 2013. Tilapia sex reversal using methyltestosterone (MT) and its effect on fish, man and environment. Biotechnology, 13: 213-216.

Received: 4 March 2019; Accepted: 20 May 2019
Minton, B.L. 2009. Drug-induced fish: hormone causes tilapia to undergo sex change. [naturalnews.com/ 026006_fish_tilapia_testosterona_html]. Reviewed: January 10, 2019.

Nagler, J.J., Cavileer, T., Sullivan, J., Cyr, D.G. \& Rexroad, C. 2007. The complete nuclear estrogen receptor family in the rainbow trout: discovery of the novel ER $\alpha 2$ and both ER $\beta$ isoforms. Gene, 392(1): 164-173.

Nebo, C. Portella, M.C., Carani, F.R., de Almeida, F.L., Padovani, C.R., Carvalho, R.F. \& Dal-Pai-Silva, M. 2013. Short periods of fasting followed by refeeding change the expression of muscle growthrelated genes in juvenile Nile tilapia (Oreochromis niloticus). Comparative Biochemistry and Physiology Part B: Biochemistry and Molecular Biology, 164(4): 268-274.

Norbeck, L.A. \& Sheridan, M.A. 2011. An in vitro model for evaluating peripheral regulation of growth in fish: effects of $17 \beta$-estradiol and testosterone on the expression of growth hormone receptors, insulin-like growth factors, and insulin-like growth factor type 1 receptors in rainbow trout (Oncorhynchus mykiss). General and Comparative Endocrinology, 173(2): 270-280.

Ong, S.K., Chotisukarn, P. \& Limpiyakorn, T. 2012. Sorption of $17 \alpha$-methyltestosterone onto soils and sediment. Water, Air, \& Soil Pollution, 223(7): 38693875.

Oponda, C.V.L., Santos, B.S. \& Basiao, Z.U. 2017. Morphological differences in five strains of genetically improved Nile tilapia (Oreochromis niloticus) using geometric morphometrics. Journal of the International Society for Southeast Asian Agricultural Sciences, 23: 44-55.

Passantino, A. 2012. Steroid hormones in food producing animals: regulatory situation in Europe. A bird's-eye view of veterinary medicine. InTech Open, London, pp. 33-50.

Santos, V.B., Mareco, E.A. \& Dal-Pai-Silva, M. 2013. Growth curves of Nile tilapia (Oreochromis niloticus) strains cultivated at different temperatures. Acta Scientiarum Animal Sciences, 35(3): 235-242.

Strauss, R.E. \& Bookstein, F.L. 1982. The truss: body form reconstructions in morphometrics. Systematic Biology, 31(2): 113-135.

Wassermann, G.J. \& Afonso, L.O.B. 2003. Sex reversal in Nile tilapia (Oreochromis niloticus Linnaeus) by androgen immersion. Aquaculture Research, 34(1): 65-71. 